\title{
EDUCAÇÃO AMBIENTAL E COMUNICAÇÃO
}

\section{Educação ambiental não se aprende só na escola; os meios de comunicação têm um papel a desempenhar no esclarecimento do conjunto da população}

A Terra tem cinco bilhões de anos e provou ter grande capacidade de recuperação. Nos 3,5 bilhões de anos, desde o aparecimento das primeiras formas de vida, espécies biológicas surgiram, desapareceram e a vida não sofreu interrupções. Mas, as mudanças por que passa nosso planeta são diferentes das mudanças anteriores em termos de escala e de ritmo. Só para citar um exemplo, a cada ano 200 milhões de toneladas de solo fértil são levadas pela rede de drenagem para fora do território do Estado de São Paulo pelo inadequado manejo agrícola. As perdas do solo são muitas vezes superiores à recuperação natural.

Tais mudanças ambientais colocaram o homem diante de dois grandes temas de repercussão mundial e que dizem respeito a seu destino: a destruição acelerada do Meio Ambiente e, paralelamente, o avanço da Tecnologia. As relações homem/máquina e homem/natureza são questões atuais que im-

\section{OS AUTORES}

\section{Gláucia Davino}

Doutoranda junto ao Departamento de Comunicações e Artes da ECA-USP.

André Davino

Professor Titular em Geociências, na USP, e Engenheiro Geofísico pelo Instituto Francês do Petróleo. Foi assessor da Secretaria Municipal do Meio Ambiente de Ribeirão Preto (1991-1993). plicam estudos específicos nas diversas áreas do conhecimento humano: Cibernética, Sociologia, Comunicação, Geologia, Política etc. Nestas relações o homem é o centro produtor e o centro receptor das consequiências de sua própria ação. Por isso temas como os computadores e a transformação da percepção do homem ou as doenças causadas pela poluição do ar e pela vida sedentária estão intimamente inseridos na interação Meio Ambiente/ Homem/ Tecnologia.

Se por um lado investimentos maciços em tecnologia vêm proporcionando maior conforto à sociedade humana, por outro estão transformando o meio ambiente, podendo levar a camada de ozônio à exaustão, as florestas tropicais ao desmatamento, à formação de depósitos de ácidos e à concentração de gases na atmosfera, impedindo a dispersão do calor e, em consequiência, elevando a temperatura da Terra.

A tecnologia e os benefícios que dela advêm é certamente um caminho irreversível. Como poderia o homem moderno viver sem os meios de transporte e de comunicação, sem as habitações modernas e funcionais; sem os sistemas de produção de alimentos em larga escala?

A questão do meio ambiente tem implicações tanto científicas (a necessidade de pesquisas especializadas sobre o meio ambiente e áreas correlatas), quanto políticas (a organização da sociedade e o exercício do poder dos partidos nas democracias). 
Baseada nas melhores informações que a ciência tem a oferecer, a questão do meio ambiente envolve tomadas de decisões de riscos e possíveis conseqüências econômicas. Por isso é importante que o público também fique informado e se envolva nessas discussões.

Os meios de comunicação de massa, também filhos diretos do desenvolvimento da tecnologia moderna, constituem um dos instrumentos mais adequados para veicular parte da educação ambiental e promover as bases do debate que mal se inicia.

\section{MÍDIA ECOLÓGICA}

Os meios de comunicação, principalmente a mídia impressa e eletrônica, têm sido usados com parcimônia na divulgação de assuntos pertinentes ao meio ambiente. Como são reduzidos os canais de Televisão Educativa, cuja função primordial é oferecer ao público o que as TV comerciais não oferecem, reduzido conhecimento é transmitido aos telespectadores. Também os demais meios de comunicação pouco oferecem nesse sentido.

Em São Paulo, a única emissora preocupada em veicular com certa freqüência programas sobre o tema é a TV Cultura. Exemplos de programas com temáticas relacionadas ao meio ambiente são Planeta Terra, Repórter Eco, Mundo Animal. São programas produzidos fora do Brasil, de excelente qualidade técnica, que nos fazem mergulhar nos mistérios e encantos da Natureza. Como numa deliciosa viagem turística passamos de um lugar a outro do globo terrestre, passeamos por belíssimas paisagens, visitamos diferentes povos, conhecemos inti- mamente o ciclo da vida de grupos de animais, vemos o inverno do urso Panda e outros assuntos. Enquanto isso, outras emissoras ou mesmo os jornais impressos e revistas noticiam a seca, as enchentes, o ataque dos gafanhotos etc.

Os meios de comunicação acabam selecionando como notícias sobre o meio ambiente apenas aquelas poucas que causam impactos emocionais e sensacionalistas. É comum que crianças sejam convocadas a abraçar um jatobá condenado a ser derrubado pelas autoridades, quando, na realidade, o município que abriga aquela velha árvore em extinção, deveria cuidar de seu reflorestamento.

Em São Paulo, por exemplo, mais de um milhão de árvores deveriam estar sendo plantadas, apenas para satisfazer os dispositivos legais do reflorestamento $-20 \%$ de cobertura vegetal para cada propriedade.

Neste caso, a manifestação das crianças passa a constituir um acontecimento "folclórico". A obrigatoriedade por lei de se plantar, por exemplo, 100 novos jatobás para cada um que fosse condenado e derrubado deveria se impor. Os meios de comunicação optam pela primeira forma de abordagem do tema, criando um universo místico e confuso em relação ao que seja Meio Ambiente, o qual é, muitas vezes, confundido como sendo apenas (e não menos importante) a ecologia, o ecossistema, a cadeia alimentar, as flores na janela e os casacos de pele.

Há um alto grau de complexidade implícito no termo Meio Ambiente, por sua abrangência e por suas implicações econômicas, sociais e políticas. Disso resultam dificuldades para se impor normas e disposições disciplinadoras das ações que envolvem esta área do conhecimento. 
O meio ambiente abrange todos os bens naturais, artificiais e culturais, de valor juridicamente protegido, tais como 0 ar, o solo, o subsolo, as águas, as belezas naturais, a fauna, a flora, as belezas artificiais, o patrimônio histórico, artístico, paisagístico, arqueológico e arquitetônico. $\mathrm{O}$ meio ambiente é tudo o que cerca o ser humano e é capaz de influenciar sua existência.

O meio ambiente, portanto, não inclui apenas os aspectos naturais da Terra, ou seja, os aspectos físicos e biológicos, mas, igualmente, aspectos artificiais e culturais (os chamados bens antrópicos). Assim, a cidade de Ouro Preto (MG), o conjunto arquitetônico do Pelourinho em Salvador (BA), a Catedral de São Paulo, por constituírem valores juridicamente protegidos, fazem parte do meio ambiente.

O quadro abaixo permite apreciar a abrangência dessa área do conhecimento.

\begin{tabular}{|c|c|c|}
\hline \multicolumn{3}{|c|}{ MEIO AMBIENTE } \\
\hline ARTIFICIAIS/CULTURAIS & NATUR & AIS \\
\hline ANTRÓPICO & Físico & BIOLÓGICO \\
\hline $\begin{array}{l}\text { - belezas artificiais } \\
\text { - patrimônio histórico } \\
\text { - patrimônio artístico } \\
\text { - patrimônio paisagístico } \\
\text { - patrimônio arqueológico } \\
\text { - patrimônio arquitetônico }\end{array}$ & $\begin{array}{l}\cdot \text { - ar } \\
\cdot \text { solo } \\
\text { e subsolo } \\
\text { - águas } \\
\text { - belezas } \\
\text { naturais }\end{array}$ & $\begin{array}{l}\text { - fauna } \\
\text { - flora }\end{array}$ \\
\hline
\end{tabular}

\section{DEGRADAÇÃO DO MEIO AMBIENTE}

De um modo genérico, pode-se apontar três causas para a sua degradação:

A explosão demográfica é o resultado do crescimento logarítmico da população da Terra. Hoje mais de 5 bilhões de pessoas têm necessidades crescentes de consumo de alimento, de lazer, de insumos naturais e de energia, devido à desordenada expansão urbana.
A revolução verde revela a crescente expansão das áreas agricultáveis para suprir as necessidades de alimentos e o manejo agrícola, causando grande prejuízo ao solo.

A revolução industrial, base do desenvolvimento acelerado, com as indústrias despejando na atmosfera e nas águas rejeitos tóxicos em quantidades que já comprometem o equilíbrio dos recursos naturais e a saúde da população.

As consequiências da degradação podem ser sentidas nos exemplos que se seguem:

Meio Físico: poluição do ar; erosão acelerada do solo; degradação do subsolo; poluição e superexploração das águas; alteração da paisagem, entre outros

Meio Biológico: extinção de espécies e despovoamento; rompimento dos ecossistemas; desmatamentos

Meio Antrópico: uso e ocupação do solo com criação de áreas de riscos (assoreamento, inundações) e insalubridade; poluição sonora e visual; degradação do patrimônio artístico-cultural

\section{ASPECTOS JURÍDICOS}

A preocupação com o meio ambiente faz parte de um processo que não é instantaneamente constituído. $\mathrm{O}$ embasamento jurídico sobre questões ambientais vem sendo elaborado na medida em que se cria consciência dos problemas envolvendo a degradação do meio ambiente. Se não há lei que estabeleça uma área de preservação de Mata Atlântica, por exemplo, e que delimite a ação do homem dentro destas regiões, nada impedirá que qualquer cidadão construa uma cabana, um belo prédio de apartamentos, ruas ou um clube, no local. Foi em nome do progresso e sem leis ambientalistas (não necessárias na época) que os EUA de- 
vastaram grandes áreas de florestas nativas. Isso significa, então, que para uma Educação Ambiental consistente é necessária a clara compreensão de que existe ou deve existir uma consistente atuação jurídica neste complexo conjunto.

A abordagem feita pelos meios de comunicação sobre a existência de aspectos jurídicos, visando à educação e à conscientização sobre os problemas que afetam o meio ambiente é nula. Eventualmente aspectos jurídicos entram em pauta quando, por exemplo, estão noticiando conflitos referentes às delimitações das áreas indígenas Ianomâmi, no Norte do país. Delimitar áreas, por parte do Estado, é um dos aspectos jurídicos relativos à preservação do meio ambiente. Estas abordagens, porém, vêm à público em forma fragmentada durante um noticiário e não de uma forma com fins de esclarecimento educativo, para que se possa refletir sobre a importância de uma ou de outra decisão para o bem-estar do próprio país.

$\mathrm{O}$ meio ambiente é patrimônio público a ser necessariamente assegurado e protegido, tendo em vista o uso coletivo. O Direito Ambiental, além de normas preventivas, tem dispositivo de caráter sancionador contra lesões ou ameaça a direito, relacionado, direta ou indiretamente, com o patrimônio ambiental cultural equilibrado e juridicamente protegido.

A Constituição Brasileira de 1988, artigo 225, contém o seguinte dispositivo: “O Meio Ambiente, ecologicamente equilibrado, constitui Direito de todos, bem de uso comum do povo e essencial à sadia qualidade de vida, impondo-se ao Poder Público e à coletividade o dever de defendê-lo e preservá-lo para a presente e futuras gerações."
Em 1988, criou-se no Brasil legislação para análise dos impactos ambientais: EIA-RIMA (Estudos de Impactos Ambientais e Relatórios de Impactos sobre o Meio Ambiente) que disciplinam previamente os projetos de implantação de obras capazes de provocar ações cujo balanço final é desfavorável e leva à degradação do meio ambiente.

\section{PROBLEMAS}

Quem se ocupa de problemas do meio ambiente sabe que seus temas são amplos e polêmicos. Eles podem ser tratados em diferentes níveis: (a) na escala da Terra, (b) na escala de um país e (c) na escala da localidade.

Em nível local, pode-se atender uma região de vários municípios, um só município, uma bacia hidrográfica ou microbacia. Muitos dos problemas deveriam ser tratados sempre que possível em nível de microbacias, por ser esta uma unidade natural e delimitada, com inúmeras vantagens para a solução de problemas. Tem prevalecido, no entanto, a política municipalista consubstanciada na afirmação: "pensar globalmente e agir localmente".

A ação e a luta política dicotomizam as questões ambientais: até que ponto a preocupação com o meio ambiente pode estancar o progresso? A resposta de William Reilly, administrador da E.P.A., Agência de Proteção Ambiental dos EUA, foi:"Estou convencido de que a saída para o meio ambiente é o desenvolvimento e não o estancamento do progresso em nome da conservação da Natureza. Atualmente a palavra-chave do conservadorismo é criação e não apenas proteção"1. 
Em nossa opinião, para países que contam com escassos recursos para os problemas de meio ambiente, como é o caso do Brasil, a melhor maneira de se lidar com esse tema é em nível local — o Município ou Consórcio de Municípios.

Cada local possui seus problemas próprios. Um município situado num contexto geomorfológico como Campos do Jordão (SP), com vocação turística, não apresenta problemas semelhantes aos de Ribeirão Preto (SP), situado na borda da Bacia Sedimentar do Paraná, com relevo suave e vocação agrícola. Ambos os municípios apresentam problemas ambientais muito diversos de municípios situados na região amazônica, por exemplo.

A programação para o meio ambiente na localidade pode ser elaborada dentro de três itens:

Educação Ambiental: seu objetivo é a conscientização do cidadão para a problemática da preservação do meio ambiente, bem como obter seu apoio e contribuição para as campanhas que envolvam o trabalho de toda a população.

Cartas Temáticas dos Aspectos Ambientais: tem por objetivo servir de embasamento para o estudo do diagnóstico de diretrizes para o Uso e Ocupação do Solo de um determinado município ou conjunto de municípios. A carta hidrogeológica, a carta da distribuição da vegetação remanescente primária, a carta de distribuição das escolas de primeiro grau são exemplos de cartas temáticas de interesse do meio ambiente e do planejamento racional do município.

Áreas Degradadas e Poluição: a definição de Áreas Degradadas e de Poluição depende do estado de desenvolvimento do município. Para cada um deles serão definidas áreas prioritárias. Assim, por exemplo, o reflorestamento de espécies naturais é de fundamental importância para o município de Ribeirão Preto.
No quadro abaixo, esses três itens são explicitados.

\section{PROGRAMAS}

— EDUCAÇÃO AMBIENTAL

- Rede de Ensino

- População

- Normas e Padrões Ambientais

— CARTAS TEMÁTICAS

- Planialtimétrica

- Condições Climáticas

- Solos

- Geomorfológica

- Hidrogeológica

- Geotécnica

- Recursos minerais

- Vegetação remanescente

- Ocupação agrosilvopastoril

- Distribuição da fauna

- Uso e ocupação do solo

- Distribuição demográfica

- ÁREAS DEGRADADAS E POLUIÇÃO

- Reflorestamento

- Recursos hídricos

- Lixo e esgoto

- Expansão urbana

\section{COMUNICAÇÃO \\ E EDUCAÇÃ O AMBIENTAL}

Enquanto as Cartas Temáticas e as Áreas Degradadas e Poluição se inserem mais apropriadamente no domínio técnico, a Educação Ambiental é por excelência a área a que os meios de comunicação devem emprestar seus recursos e potencialidades.

A Educação Ambiental pode se fazer em nível de municípios ou de um consórcio de municípios, junto à rede de ensino públi- 
ca e privada e junto à população em geral. Deve incluir a divulgação de Normas e Padrões Ambientais.

A reciclagem do lixo, por exemplo, é um fracasso em quase todos os países periféricos, primeiramente por ser dez vezes mais dispendiosa e segundo porque deve contar com a ajuda da população, o que só pode ser obtido através do uso intenso e esclarecedor dos veículos de comunicação. Sem a cooperação da população, não há reciclagem; sem conscientização, não há cooperação; e sem o uso inteligente da mídia, não há conscientização.

O lixo constitui um problema ambiental grave, mormente se atentarmos para o fato de que, nas regiões industrializadas, cada habitante produz o correspondente a cerca de meio a um quilo de lixo por dia. Em São Paulo, 10.000 toneladas de lixo devem ser dispostas por dia e, em Ribeirão Preto, 200 toneladas são enviadas para o aterro sanitário. $O$ lixo pode poluir o ar, o solo e as águas e constituir um agente transmissor de doenças.

A disposição final de lixo nos aterros, em contato com as águas da chuva, produz um líquido preto-esverdeado, denominado chorume, que carreia substâncias tóxicas, radioativas, metais pesados e microorganismos. Além disso, o lixo induz à proliferação de ratos, insetos, aves, vetores transmissores de doenças.

Citamos a reciclagem e a disposição final do lixo nos aterros como exemplo claro de aplicação na Educação Ambiental, por serem temas de grande atualidade e muito divulgados nos meios de comunicação. Outros temas, porém, apresentam a mesma ou até maior relevância que o lixo, tais como: o reflorestamento por plantas nativas, a prote- ção dos recursos hídricos subterrâneos contra a poluição e a superexploração, a coleta e tratamento de esgotos, o uso e ocupação do solo e a expansão urbana.

Ao contrário do que podem sugerir informações esparsas que priorizam sobretudo assuntos de impacto comercial, os temas prioritários ligados ao meio ambiente, em nível de município, são de fácil compreensão e de simples realização. No entanto precisam contar com instrumentos adequados para uma política de ação didático-educacional, embasada em conclusões científicas e voltada à proteção do meio ambiente em sintonia com o progresso tecnológico, econômico e social.

\section{Para saber mais sobre 0 assunto ver:}

DAVINO, A. O Meio Ambiente e o uso e ocupação do solo em Ribeirão Preto. Secretaria do Meio Ambiente de Rib. Preto (distribuição interna), 1992.

\section{O Meio Ambiente e o planeja-} mento do município de Ribeirão Preto. Secretaria do Meio Ambiente de Rib. Preto (distribuição interna), 1992.

GREENFIELD, P.M. O desenvolvimento do raciocínio na era da eletrônica. São Paulo: Summus, 1988.

SIMON, C. Uma terra, um futuro. São Paulo: Makron Books, 1992.

SOUZA, A. DAVINO, A. et al. Programa de reflorestamento em nível de microbacias hidrográficas. Secretaria do Meio Ambiente de Rib. Preto (distribuição interna), 1992.

STERN, P.et al. Mudanças e agressões ao Meio Ambiente. São Paulo: Makron Books, 1993. 